vice versa. This is an important factor to remember, for if an adult cuff is used on a child clinically significant hypertension may be missed. Cuff length is also important: the inflatable bag should surround the whole arm, for if it is short unduly high readings will be obtained. ${ }^{4}$ The usual standard cuff of $12 \times 23 \mathrm{~cm}$ is too short for this, and further assessment of a $12 \times 35 \mathrm{~cm}$ cuff is proposed, though the suggestion that this size is the correct standard ${ }^{1}$ seems unlikely to be followed widely in Britain, and we must accept that there is generally a small error.

Blood pressure is measured by auscultation of the Karotkoff sounds as the pressure in the cuff falls. The cuff should fit snugly, since pain from too tight a cuff will provoke a rise in pressure. Prolonged venous occlusion from repeated inflation may cause error. The arm should res1 at heart level. Preliminary assessment of the systolic pressure by palpation of the radial artery will allow the cuff pressure to be raised to $30 \mathrm{~mm} \mathrm{Hg}$ above the systolic pressure before auscultation begins. Cuff pressure should then be reduced by $2-3 \mathrm{~mm} \mathrm{Hg}$ with each beat, and the appearance of the Karotkoff sounds (phase 1) gives the systolic blood pressure. The best diastolic value is obtained as the Karotkoff sounds become muffled (phase IV); this criterion is now recommended ${ }^{5}$ even in the USA, but continued use of the previously recommended criterion of disappearance of the sounds (phase V) still causes some confusion. ${ }^{2}$

Unconscious digital preference (rounding off the reading to the nearest $10 \mathrm{~mm} \mathrm{Hg}$ ) should be avoided, but great accuracy is not possible as the pressure in the cuff falls between pulses and the blood pressure varies with respiration; adjustment to the nearest $5 \mathrm{~mm} \mathrm{Hg}$ seems reasonable. (For the time being no conversion to SI units should be made-kilopascals are reserved for direct measurements of arterial pressure.) For epidemiological studies and other research a covered sphygmomanometer is generally recommended so that the observer does not know the pressure recorded as the measurement is made. ${ }^{6}$

\footnotetext{
1 Thulin, T, Anderson, G, and Scherstén, B, Postgraduate Medical fournal, 1975, 51, 390.

2 Short, D, Lancet, 1974, 2, 645

${ }^{3}$ Smirk, P H, High Arterial Pressure. Springfield, Charles C Thomas, 1957.

4 Simpson, J A, et al, American Heart fournal, 1965, 70, 208.

5 Kirkendall, W H, et al, Circulation, 1967, 36, 980.

${ }^{6}$ Rose, G A, Holland, W W, and Crowley, E A, Lancet, 1964, 1, 296.
}

\section{Vibration syndrome}

In its 1975 report on the vibration syndrome ${ }^{1}$ the Industrial Injuries Advisory Council drew attention to a common occupational disease first described by Loriga ${ }^{2}$ in 1911. Maurice Raynaud-a French physician-described the phenomenon of finger blanching on exposure to cold in an MD thesis ${ }^{3}$ entitled "De l'asphyxie locale et de la gangrène symetrique des extrémités" and his name has been associated with it since. We now recognise a primary state, Raynaud's disease or constitutional white finger, which is familial; and secondary Raynaud's phenomenon, arising from some connective tissue disorders and from changes induced by intoxication with chemicals such as vinyl chloride or by trauma, including vibration. Vibration white finger has been described in workers in several occupations including limestone quarrymen ${ }^{4}$; grinders $^{5-8}$; and chain-saw users. ${ }^{9} 10$
The Industrial Injuries Advisory Council was asked in 1950-4 to consider whether Raynaud's phenomenon should be prescribed as an industrial disease. ${ }^{11}$ Nevertheless, the application was rejected on the grounds that the disablement was minimal; the incapacity lasted only for short intervals in cold weather; there would be difficulty in distinguishing between occupational and non-occupational cases; and there would be a problem of assessing disability. The council started to reconsider the question in 1967 and issued an interim report ${ }^{12}$ in 1970, having received evidence from a research project conducted by Stewart. ${ }^{13}$ The final report referred to a further research project, the findings of which have now been published ${ }^{14}$, and these include a comprehensive review of past and present knowledge of the syndrome with particular reference to grinders and chain-saw users in the United Kingdom. These research results have advanced knowledge of the progression of the syndrome in workers who continue and discontinue vibration exposure. But, while the results of the tests used to assess neurological and vascular function and temperature show broad differences between groups of workers exposed to vibration and controls, none of the tests can with any certainty identify an individual with vibration white finger. Nor was any statistically significant difference in the total number of bone cysts found between those exposed to vibration and the controls.

While recognising that there is no doubt that vibrating tools lead to a condition in the fingers which affects several thousands of people, the council declined to recommend prescription because normally vibration white fingers amounts to no more than temporary inconvenience. At worst it can lead to a change of job and a substantial loss of earnings, but such cases are few. The basic reason that prescription has been refused again is that no objective clinical tests are available (or likely to be devised) which would reliably establish the existence of the condicion, determine its origin, or enable a reasonably accurate assessment of disablement to be made.

Taylor and Pelmear ${ }^{14}$ have made a strong plea for prevention, repeated in their evidence, in which they referred to the new BSI Draft Standard on Vibration. ${ }^{15}$ The council report, while stating that the question of prevention is a matter for the Health and Safety Commission, urged that the commission's attention be drawn to the measures that can be and are being taken to reduce the hazards of vibration. To reduce the exposure of employed persons to vibration and to prevent severe complications, a code of practice is clearly very necessary-and long overdue.

${ }^{1}$ Industrial Injuries Advisory Council Report, Vibration Syndrome, cmnd 5965. London, HMSO, 1975.

${ }^{2}$ Loriga, G, quoted by Teleky, L, Occupation and Health Supplement. Geneva, ILO, 1938.

${ }^{3}$ Raynaud, M, in Selected Monographs. London, New Sydenham Society, 1888.

${ }^{4}$ Hamilton, A, Bulletin 236, US Bureau of Labor Statistics, 1918, 19, 53.

5 Seyring, M, Bulletin of Hygiene, 1931, 6, 25.

${ }^{6}$ Agate, J N, Druett, H A, and Tombleson, J B L, British fournal of Industrial Medicine, 1946, 3, 167.

7 Agate, J N, British fournal of Industrial Medicine, 1949, 6, 144

8 Jepson, R P, British fournal of Industrial Medicine, 1954, 11, 180

9 Grounds, M D, Medical Fournal of Australia, 1964, 1, 270.

10 Taylor, W, et al, British fournal of Industrial Medicine, 1971, 28, 83.

11 Industrial Injuries Advisory Council Report, Raynaud's Phenomenon, cmnd 9347. London, HMSO, 1954.

12 Industrial Injuries Advisory Council Interim Report, Vibration Syndrome, cmnd 4430. London, HMSO, 1970.

13 Stewart, A M, and Goda, D F, British fournal of Industrial Medicine, 1970, 27, 19.

14 Taylor, W, and Pelmear, P L, Vibration White Finger in Industry. London and New York, Academic Press, 1975.

15 Draft BSI Standard-Guide to the Evaluation of Exposure of the Human Hand-arm System to Vibration. DD43, BSI, 1975. 